\title{
Efektivitas Dexmedetomidine terhadap Kadar Kortisol pada Pasien yang Menjalani Operasi Ginekologi dalam Anestesi Umum
}

\author{
Yuliana, ${ }^{1,2}$ Rose Mafiana, ${ }^{1}$ Agustina Br. Haloho, ${ }^{1}$ Theodorus ${ }^{3}$ \\ ${ }^{1}$ Bagian Anestesiologi dan Terapi Intensif Fakultas Kedokteran Universitas Sriwijaya/RSUP Dr. \\ Mohammad Hoesin Palembang, ${ }^{2}$ Departemen Anestesiologi FKIK Unika Atma jaya, \\ ${ }^{3}$ Bagian Farmakologi FK Universitas Sriwijaya
}

\begin{abstract}
Abstrak
Respons stres adalah perubahan hormon dan metabolik yang terjadi setelah trauma seperti pembedahan, salah satunya terjadi peningkatan kadar kortisol. Dexmedetomidine dapat menurunkan respons stres dengan menghambat sintesis kortisol. Tujuan penelitian ini adalah mengetahui efek dexmedetomidine terhadap kadar kortisol pada pasien yang menjalani operasi ginekologi dalam anestesi umum yang dilakukan di RSUP dr. Mohammad Hoesin Palembang dari Januari-Maret 2018. Jumlah sampel 30 orang yang dibagi menjadi 2 kelompok, kelompok dexmedetomidine dan kelompok plasebo. Kelompok dexmedetomidine mendapatkan dosis dexmedetomidine awal $1 \mu \mathrm{g} / \mathrm{kgBB}$ selama 10 menit dilanjutkan $0,5 \mu \mathrm{g} / \mathrm{kgBB} / \mathrm{jam}, 20$ menit sebelum induksi. Pada kelompok plasebo menggunakan $\mathrm{NaCl} \mathrm{0,9 \% .} \mathrm{Induksi} \mathrm{menggunakan} \mathrm{propofol,} \mathrm{fentanil} 2 \mu \mathrm{g} /$ $\mathrm{kgBB}$, dan atrakurium $0,5 \mu \mathrm{g} / \mathrm{kgBB}$ serta pemeliharaan menggunakan sevofluran $3 \%$ dalam 02 dan N2O 50\%:50\%. Kemudian 1 jam pascaekstubasi diambil sampel darah kembali untuk pemeriksaan kadar kortisol. Hasil penelitian pada kedua kelompok terjadi peningkatan kadar kortisol saat 1 jam pascaekstubasi dibanding dengan awal $(9,638 \pm 7,082 \mu \mathrm{g} / \mathrm{dL}$ menjadi $14,503 \pm 7,082 \mu \mathrm{g} / \mathrm{dL}$ pada kelompok dexmedetomidine dan $10,276 \pm 3,166 \mu \mathrm{g} / \mathrm{dL}$ menjadi $19,99 \pm 6,273 \mu \mathrm{g} / \mathrm{dL}$ pada kelompok placebo). Namun, kadar kortisol signifikan lebih tinggi pada kelompok plasebo. Simpulan, pada kedua kelompok terjadi peningkatan kadar kortisol dibanding dengan nilai awal, tetapi kadar lebih rendah pada kelompok dexmedetomidine.
\end{abstract}

Kata kunci: Dexmedetomidine, kortisol, operasi ginekologi, respons stres

\section{Effectiveness of Dexmedetomidine on Cortisol Level in Patients Undergoing Gynecologic Surgery under General Anesthesia}

\begin{abstract}
Stress response is a term used to define the metabolic and hormonal changes following an injury or trauma, including as surgery. One of the responses is an increase in cortisol release. Dexmedetomidine may attenuate stress response by inhibiting cortisol synthesis. The aim of this study was to determine the effects of dexmedetomidine on cortisol level, compared to placebo, in patients undergoing major gynecological surgery under general anesthesia. A double-blind randomized clinical trial was performed at Mohammad Hoesin General Hospital from January to March 2018. There were thirty samples that were divided into two groups, dexmedetomidine group and placebo group. The dexmedetomidine group received an initial dexmedetomidine loading dose of $1 \mu \mathrm{g} \mathrm{kg}-1$ over $10 \mathrm{~min}$, followed by $0.5 \mu \mathrm{g} \mathrm{kg}-1 \mathrm{~h}-120$ minutes before induction. In the placebo group, $0.9 \%$ sodium chloride was administered. Anesthesia was induced with propofol, $2 \mu \mathrm{g} / \mathrm{kgBW}$ fentanyl, and $0.5 \mathrm{mg} / \mathrm{kgBW}$ atracurium and was maintained with $3 \%$ sevoflurane in O2 and N20 50\%:50\%. After standard monitoring was established, blood samples were collected for cortisol plasma testing at baseline and 1 hour post-extubation. Hemodynamic data were recorded intraoperatively and postoperatively. Results in both groups presented a significant increase in cortisol level relative to the baseline at 1 hour post-extubation $(9.638 \pm 7.082 \mu \mathrm{g} / \mathrm{dL}$ to $14.503 \pm 7.082 \mu \mathrm{g} / \mathrm{dL}$ in dexmedetomidine group and $10.276 \pm 3.166 \mu \mathrm{g} / \mathrm{dL}$ to $19.99 \pm 6.273 \mu \mathrm{g} / \mathrm{dL}$ in placebo group [P value $<0.05$ ]) with a significantly higher corticsol level in the placebo group when compared to the dexmedetomidine group ( $\mathrm{P}$ value $<0.05)$. In conclusion, the plasma cortisol level was found to increase significantly relative to baseline level in both groups. However, the increase was significantly lower in the dexmedetomidine group.
\end{abstract}

Key words: Cortisol, dexmedetomidine, gynecology surgery, stress response

Korespondensi: Yuliana, dr, Fakultas Kedokteran Universitas Sriwijaya/FKIK Atma Jaya, Jl. Dr. Mohammad Ali, Sekip Jaya, Kec. Kemuning, Palembang, Sumatera Selatan, Tlpn (021)-5688852, Email: yulianan.lim@gmail.com 


\section{Pendahuluan}

Pembedahan dapat mencetuskan perubahan metabolik dan hormon yang disebut respons stres. Respons stres terhadap pembedahan meliputi perubahan pada sistem endokrin, imunologi, dan juga hematologi. Dari sistem endokrin terjadi peningkatan sekresi hormon, salah satunya adalah sekresi kortisol dari korteks adrenal. ${ }^{1-3}$ Kortisol memengaruhi metabolisme karbohidrat, protein, dan lemak dengan salah satu efek adalah peningkatan kadar glukosa yang akan mengganggu pada penyembuhan luka, meningkatkan risiko infeksi, dan memperlama penyembuhan. ${ }^{2,4,5}$

Pembedahan merupakan salah satu pencetus utama sekresi kortisol. Kadar kortisol dapat diukur dalam beberapa menit setelah operasi dimulai. ${ }^{3}$ Ada beberapa hormon yang dapat berperan sebagai penanda respons stres, namun kortisol dipilih dalam penelitian ini karena kortisol dapat berfungsi sebagai penanda proses penyembuhan merupakan salah satu masalah yang utama setelah pembedahan. ${ }^{6}$

Dexmedetomidine dipilih dalam penelitian ini karena termasuk obat yang relatif baru dan mempunyai efek menurunkan sintesis kortisol, simpatolitik dengan mekanisme bekerja di sentral yang dapat mengaktifkan reseptor pascasinaps $\alpha_{-}$adrenergik sehingga terjadi penurunan pelepasan norepinefrin yang akan menurunkan tekanan darah dan laju jantung, serta berperan penting dalam proteksi organ vital yaitu otak, jantung, dan ginjal yang membedakannya dengan obat anestesi lain. ${ }^{6}$

Tujuan penelitian ini adalah mengetahui efek dexmedetomidine intravena terhadap kadar kortisol pada pasien yang menjalani operasi ginekologi dalam anestesi umum.

\section{Subjek dan Metode}

Penelitian ini merupakan sebuah penelitian eksperimental dengan teknik acak tersamar ganda yang dilakukan di RSUP dr. Mohammad Hoesin Palembang dari bulan Januari-Maret 2018 dengan sertifikat persetujuan etik
Nomor 31/kepkrsmhfkunsri/2018. Kriteria inklusi pada penelitian ini adalah pasien yang dijadwalkan untuk operasi ginekologi dalam anestesi umum, lama operasi 90-180 menit, dan status fisik ASA I-II, usia 17-64 tahun, Indeks massa tubuh (IMT) 18,6-29,9 kg/ $\mathrm{m}^{2}$.

Kriteria eksklusi adalah hipertensi, hipotensi, penyakit jantung koroner, gangguan blok, alergi terhadap obat anestesi, hipovolemia, bradikardia, riwayat penyakit endokrin, pasien dalam terapi kortikosteroid. Pasien dikeluarkan dari penelitian jika terjadi komplikasi perioperatif seperti syok, reaksi anafilaktik, lama operasi tidak memenuhi kriteria, atau memerlukan tambahan obat anestesi (opioid atau anestesi inhalasi).

Langkah awal yang dilakukan pasien adalah menandatangani surat persetujuan (informed consent). Kemudian, pasien dirandom secara sederhanamenjadi 2 kelompok, yaitu kelompok dexmedetomidine dan kelompok plasebo. Rumus yang digunakan untuk menentukan jumlah sampel dalam penelitian ini adalah $\mathrm{n}=2 \sigma^{2}\left(\mathrm{Z}_{1-\alpha}\right)+\left(\mathrm{Z} 1_{-\beta}\right)^{2} / \alpha^{2}$, dengan $\sigma=$ standar deviasi gabungan dari kedua kelompok, $\alpha=$ besar perbedaan rerata kadar kortisol antara kelompok dexmedetomidine dan kelompok plasebo. Dengan memperhatikan drop out sebesar $10 \%$ maka besar sampel tiap-tiap kelompok adalah 17 orang dengan jumlah sampel keseluruhan adalah 34 sampel.

Dua mililiter darah diambil dari vena mediana kubiti lengan (kontralateral dengan lengan yang terpasang infus) pada saat awal sebelum tindakan operasi atau sebelum pembiusan untuk pengukuran kadar kortisol. Kemudian, pada kelompok dexmedetomidine diberikan dexmedetomidine dosis awal loading $1 \mu \mathrm{g} / \mathrm{kgBB}$ selama 10 menit sebelum induksi, dilanjutkan dosis pemeliharaan 0,5 $\mu \mathrm{g} / \mathrm{kg} / \mathrm{jam}$ sampai operasi selesai. Kelompok plasebo diberikan $\mathrm{NaCl}$ 0,9\% dengan dosis yang sama. Selanjutnya, dilakukan induksi anestesi menggunakan propofol, fentanil 2 $\mu \mathrm{g} / \mathrm{kgBB}$, dan atrakurium $0,5 \mathrm{mg} / \mathrm{kgBB}$ serta pemeliharaan menggunakan sevofluran 3\% dalam $\mathrm{O}_{2}$ dan $\mathrm{N}_{2} \mathrm{O}$ 50\%:50\%. Setelah operasi selesai, dilakukan ekstubasi, kemudian satu jam pascaekstubasi kembali dilakukan 
Tabel 1 Karakteristik Subjek

\begin{tabular}{|c|c|c|c|}
\hline \multirow[b]{2}{*}{ Parameter } & \multicolumn{2}{|c|}{ Kelompok } & \multirow[b]{2}{*}{ Nilai p } \\
\hline & $\begin{array}{c}\text { Dexmedetomidine } \\
(\mathrm{n}=15)\end{array}$ & $\begin{array}{l}\mathrm{NaCl} 0,9 \% \\
(n=15)\end{array}$ & \\
\hline $\begin{array}{l}\text { Usia (tahun) } \\
\text { Median (min.-maks.) }\end{array}$ & $50(17-59)$ & $43(18-59)$ & $0,092^{*}$ \\
\hline $\begin{array}{l}\text { Berat badan (kg) } \\
\text { Median (min.-maks.) }\end{array}$ & $60(46-75)$ & $55(46-70)$ & $0,106^{*}$ \\
\hline $\begin{array}{l}\text { Tinggi (meter) } \\
\text { Mean } \pm \text { SD }\end{array}$ & $1,58 \pm 0,03$ & $1,57 \pm 0,04$ & $0,456^{* *}$ \\
\hline $\begin{array}{l}\text { Indeks massa tubuh }\left(\mathrm{kg} / \mathrm{m}^{2}\right) \\
\text { Median (min.-maks.) }\end{array}$ & $23(19-28)$ & $22(19-29)$ & $0,158^{*}$ \\
\hline $\begin{array}{l}\text { Lamanya operasi (menit) } \\
\text { Mean士SD } \\
\text { Waktu ekstubasi (menit) }\end{array}$ & $128,7 \pm 32,09$ & $132,0 \pm 22,26$ & $0,743^{* *}$ \\
\hline Mean \pm SD & $8,00 \pm 2,535$ & $7,67 \pm 2,582$ & $0,717^{* *}$ \\
\hline $\begin{array}{l}\text { Tekanan darah sistole (mmHg) } \\
\text { Mean } \pm \text { SD }\end{array}$ & $137,87 \pm 15,84$ & $138,8 \pm 18,41$ & $0.883^{* *}$ \\
\hline $\begin{array}{l}\text { Tekanan darah diastole }(\mathrm{mmHg}) \\
\text { Mean } \pm \text { SD }\end{array}$ & $79,87 \pm 11,55$ & $84,87 \pm 13,06$ & $0,276^{* *}$ \\
\hline $\begin{array}{l}\text { Laju nadi (kali/menit) } \\
\text { Mean } \pm \text { SD }\end{array}$ & $82,33 \pm 17,97$ & $91,0 \pm 14,51$ & $0,157^{* *}$ \\
\hline $\begin{array}{l}\text { Laju napas (kali/menit) } \\
\text { Median (min.-maks.) }\end{array}$ & $17(15-17)$ & $17(15-18)$ & $0,073^{*}$ \\
\hline $\begin{array}{l}\text { Saturasi oksigen (\%) } \\
\text { Median (min.-maks.) }\end{array}$ & $100(100-100)$ & $100(98-100)$ & $0,073^{*}$ \\
\hline $\begin{array}{l}\text { Kadar kortisol }(\mu \mathrm{g} / \mathrm{dL}) \\
\text { Mean } \pm \text { SD }\end{array}$ & $9,638 \pm 7,082$ & $10,276 \pm 3,166$ & $0,753^{* *}$ \\
\hline
\end{tabular}

Keterangan: secara statistik bermakna jika nilai $\mathrm{p}<0,05 .{ }^{*}$ Uji Mann-Whitney, **uji-t tidak berpasangan

pengambilan darah untuk pengukuran kadar kortisol. Empat pasien dikeluarkan dari penelitian ini karena lama pembedahan tidak sesuai dengan batas waktu yang ditetapkan dan ada pasien yang memerlukan tambahan dosis obat anestesi.

Data dianalisis menggunakan uji-t dan Uji Mann Whitney. Nilai yang bermakna secara statistik adalah $\mathrm{p}<0,05$. Analisis data menggunakan statistical product and servise solution (SPSS) versi 22.0.

\section{Hasil}

Karakteristik dasar sampel penelitian berdasar usia, indeks massa tubuh, lama pembedahan, parameter hemodinamik seperti tekanan darah, laju jantung, laju napas, saturasi oksigen, dan kadar kortisol dasar tidak berbeda secara signifikan ( $p>0,05$; Tabel 1).

Perbandingan kadar kortisol awal dan satu jam pascaekstubasi pada tiap kelompok dianalisis menggunakan uji-t berpasangan dan didapatkan kadar kortisol satu jam pascaekstubasi pada kelompok dexmedetomidine meningkat sebanyak 4,87 dibanding dengan kadar awal $(9,638 \pm 7,082$ $\mu \mathrm{g} / \mathrm{dL}$ menjadi $14,503 \pm 7,082 \mu \mathrm{g} / \mathrm{dL}$ ) dan pada kelompok plasebo meningkat sebanyak 9,72 $(10,276 \pm 3,166 \mu \mathrm{g} / \mathrm{dL}$ menjadi 19,99 $\pm 6,273$ $\mu \mathrm{g} / \mathrm{dL})$. Hasil tersebut berbeda secara signifikan ( $\mathrm{p}<0,05$; Tabel 2).

Perbandingan kadar kortisol satu jam pascaekstubasi antara kedua kelompok dianalisis memakai uji-t tidak berpasangan dan didapatkan bahwa kadar kortisol 
Tabel 2 Perbandingan Kadar Kortisol Sebelum Induksi dan Satu Jam Pascaekstubasi pada Tiap Kelompok

\begin{tabular}{|c|c|c|c|c|}
\hline \multirow{2}{*}{ Kelompok } & \multicolumn{2}{|c|}{ Kortisol } & \multirow{2}{*}{$\begin{array}{l}\text { Perubahan } \\
(\mu \mathrm{g} / \mathrm{dL})\end{array}$} & \multirow{2}{*}{ Nilai p } \\
\hline & Sebelum & Satu Jam Pasca & & \\
\hline Dexmedetomidine & $9,638 \pm 7,082$ & $14,503 \pm 7,082$ & $+4,87 \pm 7,954$ & $0,033^{*}$ \\
\hline $\mathrm{NaCl} 0,9 \%$ & $10,276 \pm 3,166$ & $19,99 \pm 6,273$ & $+9,72 \pm 6,378$ & $0,001^{*}$ \\
\hline
\end{tabular}

Keterangan: secara statistik bermakna jika nilai $p<0,05$. *uji-t berpasangan

satu jam pascaekstubasi pada kelompok dexmedetomidine lebih rendah dibanding dengan kelompok $\mathrm{NaCl}(14,503 \pm 7,082 \mu \mathrm{g} /$ dL vs $19,99 \pm 6,273 \mu \mathrm{g} / \mathrm{dL}$ ) dengan perbedaan

Tabel 3 Perbandingan Hemodinamik Kedua Kelompok

\begin{tabular}{|c|c|c|c|c|}
\hline Waktu & & Dexmedetomidine & $\mathrm{NaCl} 0,9 \%$ & Nilai p \\
\hline \multicolumn{5}{|c|}{ Tekanan darah sistole } \\
\hline \multirow[t]{6}{*}{ Setelah intubasi } & $\mathrm{T}_{15}$ & $103,80 \pm 11,82$ & $120,73 \pm 19,33$ & $0,007^{*}$ \\
\hline & $\mathrm{T}_{30}$ & $102,80 \pm 14,51$ & $119,53 \pm 18,04$ & $0,009 *$ \\
\hline & $\mathrm{T}_{45}$ & $101,27 \pm 11,36$ & $122,13 \pm 16,48$ & $0,001^{*}$ \\
\hline & $\mathrm{T}_{60}$ & $103,87 \pm 11,17$ & $125,00 \pm 14,02$ & $0,001^{*}$ \\
\hline & $\mathrm{T}_{75}$ & $106,27 \pm 15,20$ & $124,47 \pm 14,96$ & $0,001^{*}$ \\
\hline & $\mathrm{T}_{90}$ & $124,60 \pm 19,33$ & $124,60 \pm 19,33$ & $0,007^{*}$ \\
\hline \multirow[t]{4}{*}{ Setelah ekstubasi } & $\mathrm{T}_{30 \mathrm{E}}$ & $112,67 \pm 12,57$ & $134,73 \pm 8,811$ & $0,001^{*}$ \\
\hline & $\mathrm{T}_{60 \mathrm{E}}$ & 141 (107-147) & $110(100-141)$ & $0,001^{* *}$ \\
\hline & $\mathrm{T}_{90 \mathrm{E}}$ & $110,87 \pm 10,01$ & $138,13 \pm 8,052$ & $0,001^{*}$ \\
\hline & $\mathrm{T}_{120 \mathrm{E}}$ & $114,53 \pm 9,970$ & $137,73 \pm 9,852$ & $0,001^{*}$ \\
\hline \multicolumn{5}{|c|}{ Tekanan darah diastole } \\
\hline \multirow[t]{6}{*}{ Setelah intubasi } & $\mathrm{T}_{15}$ & $69,80 \pm 11,47$ & $77,00 \pm 12,65$ & $0,114^{*}$ \\
\hline & $\mathrm{T}_{30}$ & $69,00 \pm 11,63$ & $76,07 \pm 11,64$ & $0,107^{*}$ \\
\hline & $\mathrm{T}_{45}$ & $70,07 \pm 10,26$ & $76,53 \pm 10,95$ & $0,106^{*}$ \\
\hline & $\mathrm{T}_{60}^{45}$ & $68,80 \pm 9,901$ & $78,40 \pm 11,69$ & $0,022 *$ \\
\hline & $\mathrm{T}_{75}$ & $67,80 \pm 8,793$ & $78,47 \pm 8,052$ & $0,002^{*}$ \\
\hline & $\mathrm{T}_{90}$ & $71,40 \pm 10,87$ & $77,00 \pm 12,04$ & $0,212^{*}$ \\
\hline \multirow[t]{4}{*}{ Setelah ekstubasi } & $\mathrm{T}_{30 \mathrm{E}}$ & $67,53 \pm 7,846$ & $75,07 \pm 11,32$ & $0,043^{*}$ \\
\hline & $\mathrm{T}_{60 \mathrm{E}}$ & 67 (55-78) & $72(62-96)$ & $0,148^{* *}$ \\
\hline & $\mathrm{T}_{90 \mathrm{E}}$ & $65,60 \pm 9,303$ & $77,67 \pm 9,092$ & $0,001^{*}$ \\
\hline & $\mathrm{T}_{120 \mathrm{E}}$ & $68,60 \pm 7,288$ & $76,73 \pm 9,027$ & $0,011^{*}$ \\
\hline \multicolumn{5}{|l|}{ Laju nadi } \\
\hline \multirow[t]{6}{*}{ Setelah intubasi } & $\mathrm{T}_{15}$ & $69,00 \pm 10,58$ & $77,87 \pm 12,39$ & $0,054^{*}$ \\
\hline & $\mathrm{T}_{30}$ & $67,40 \pm 10,22$ & $77,33 \pm 12,23$ & $0,023^{*}$ \\
\hline & $\mathrm{T}_{45}$ & $65,13 \pm 8,167$ & $78,60 \pm 13,46$ & $0,003^{*}$ \\
\hline & $\mathrm{T}_{60}$ & $64,00 \pm 9,157$ & $81,33 \pm 13,64$ & $0,001^{*}$ \\
\hline & $\mathrm{T}_{75}^{60}$ & $63,20 \pm 6,774$ & $84,00 \pm 16,69$ & $0,001^{*}$ \\
\hline & $\mathrm{T}_{90}^{15}$ & $63,00 \pm 5,928$ & $86,87 \pm 18,33$ & $0,001^{*}$ \\
\hline \multirow[t]{4}{*}{ Setelah ekstubasi } & $\mathrm{T}_{30 \mathrm{E}}$ & $60,93 \pm 6,606$ & $85,53 \pm 11,51$ & $0,001^{*}$ \\
\hline & $\mathrm{T}_{60 \mathrm{E}}$ & $61,13 \pm 5,668$ & $85,87 \pm 9,598$ & $0,001^{*}$ \\
\hline & $\mathrm{T}_{90 \mathrm{E}}$ & $61,67 \pm 5,233$ & $86,60 \pm 8,322$ & $0,001^{*}$ \\
\hline & $\mathrm{T}_{120 \mathrm{E}}$ & $61(50-69)$ & $89(65-103)$ & $0,001^{* *}$ \\
\hline
\end{tabular}




\begin{tabular}{lcccc}
\hline Laju napas & & & & \\
Setelah intubasi & $\mathrm{T}_{15}$ & $12,00 \pm 0,000$ & $12,00 \pm 0,000$ & $1,000^{*}$ \\
& $\mathrm{~T}_{30}$ & $12,00 \pm 0,000$ & $12,00 \pm 0,000$ & $1,000^{*}$ \\
& $\mathrm{~T}_{45}$ & $12,00 \pm 0,000$ & $12,00 \pm 0,000$ & $1,000^{*}$ \\
& $\mathrm{~T}_{60}$ & $12,00 \pm 0,000$ & $12,00 \pm 0,000$ & $1,000^{*}$ \\
& $\mathrm{~T}_{75}$ & $12(12-20)$ & $12(12-22)$ & $0,632^{* *}$ \\
& $\mathrm{~T}_{90}$ & $12(12-22)$ & $12(12-21)$ & $0,675^{* *}$ \\
& $\mathrm{~T}_{30 \mathrm{E}}$ & $15(15-17)$ & $17(15-21)$ & $0,001^{* *}$ \\
& $\mathrm{~T}_{60 \mathrm{E}}$ & $15(14-17)$ & $17(15-20)$ & $0,001^{* *}$ \\
& $\mathrm{~T}_{90 \mathrm{E}}$ & $15(14-17)$ & $17(15-20)$ & $0,003^{* *}$ \\
& $\mathrm{~T}_{120 \mathrm{E}}$ & $15(14-17)$ & $17(15-20)$ & $0,001^{* *}$ \\
\hline
\end{tabular}

Keterangan: secara statistik bermakna jika nilai $\mathrm{p}<0,05$.* Uji t tidak berpasangan, **Uji Mann-Whitney. $\mathrm{T}_{15}, \mathrm{~T}_{30}, \mathrm{~T}_{45}, \mathrm{~T}_{60}$, $\mathrm{T}_{75}, \mathrm{~T}_{90:} 15,30,45,60,75$, dan 90 menit setelah intubasi. $\mathrm{T}_{30 \mathrm{E},} \mathrm{T}_{60 \mathrm{E}}, \mathrm{T}_{90 \mathrm{E}^{\prime}} \mathrm{T}_{120 \mathrm{E}}: 30,60,90,120$ menit setelah ekstubasi

yang signifikan $(\mathrm{p}<0,05$; Gambar 1$)$.

Perubahan hemodinamik perioperatif kedua kelompok dianalisis menggunakan uji t tidak berpasangan dan Uji Mann-Whitney parameter tekanan darah sistole menunjukkan perbedaan di semua waktu monitoring, sedangkan untuk diastole menunjukkan perbedaan pada menit ke-60, menit ke-75 setelah intubasi dan menit ke-30, ke-90, ke120 setelah ekstubasi. Parameter laju nadi menunjukkan perbedaan pada semua waktu monitoring kecuali 15 menit setelah intubasi. Parameter laju napas setelah intubasi tidak ada perbedaan, tetapi setelah ekstubasi didapatkan hasil sebaliknya (Tabel 3).

Pada kelompok dexmedetomidine terjadi bradikardia (laju nadi $<60 \times /$ menit), tetapi tidak memerlukan pemberian sulfas atropin. Tidak ada perbedaan kejadian bradikardia yang signifikan antara kedua kelompok ( $p>0,05$; Tabel 4).

\section{Pembahasan}

Karakteristikumum subjekpenelitian berdasar usia, IMT, waktu sedasi, dan parameter hemodinamik antara kedua kelompok tidak terdapat perbedaan bermakna $(p>0,05)$ sehingga kedua kelompok dapat dianggap homogen dan layak untuk dibandingkan.

Hasil penelitian ini pemberian dexmedetomidine sebelum dan selama pembedahan ginekologi didapatkan kadar kortisol yang lebih rendah dibanding dengan kelompok plasebo. Dexmedetomidine merupakan agonis $\alpha_{-}{ }_{2}$ adrenoceptor dengan mula kerja 15 menit dan mencapai kadar puncak sekitar 1 jam serta waktu paruh 2-3 jam setelah pemberian intravena. Dexmedetomidine dimulai dengan dosis awal $1 \mu \mathrm{g} / \mathrm{kgBB}$ bolus selama 10 menit dan dapat diturunkan menjadi $0,5 \mu \mathrm{g} / \mathrm{kgBB}$ pada pasien geriatri atau pada prosedur yang sederhana.

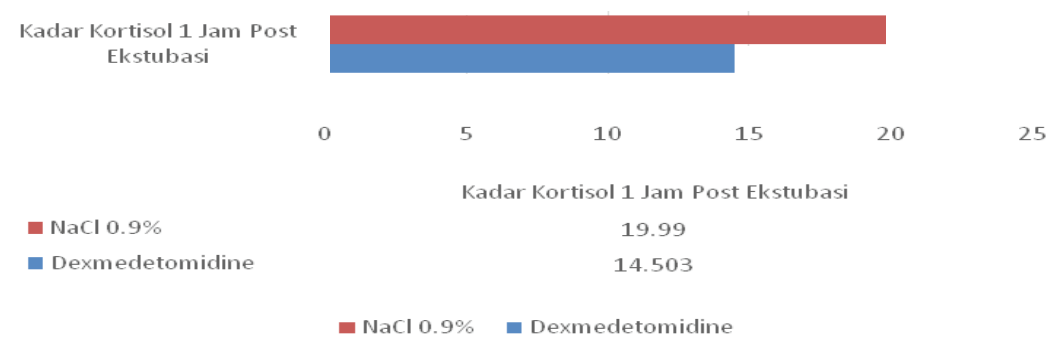

Gambar 1 Perbandingan Kadar Kortisol Satu Jam Pascaekstubasi antara 2 Kelompok 
Tabel 4 Komplikasi

\begin{tabular}{lccc}
\hline \multicolumn{1}{c}{ Komplikasi } & $\begin{array}{c}\text { Dexmedetomidine } \\
\text { n }\end{array}$ & NaCl 0,9\% & Nilai p* \\
\hline Tidak ada & 11 & 15 & 0,100 \\
Bradikardi & 4 & 0 & \\
Total & 15 & 15 & \multirow{2}{*}{. } \\
\hline
\end{tabular}

Keterangan: secara statistik bermakna jika nilai p<0,05. *Uji Eksak Fisher

Dilanjutkan dengan dosis $0,2-0,7 \mu \mathrm{g} / \mathrm{kgBB} /$ jam. Dexmedetomidine memiliki efek sedatif, analgesia, bersifat simpatolitik, dan juga dapat menurunkan kadar kortisol dengan mekanisme yang belum jelas sesuai dengan fokus penelitian ini. ${ }^{6-8}$

Kortisol merupakan hormon yang disekresikan oleh korteks adrenal lewat aksis hipotalamus-hipofisis dan korteks adrenal. Corticotropin releasing hormone yang disekresikan oleh hipotalamus akan menstimulus hipofisis anterior untuk menyekresi ACTH (adrenocorticotropic hormone). Kemudian ACTH akan menstimulus korteks adrenal untuk melepaskan hormon kortisol dalam waktu beberapa menit setelah stres, dari kadar paling rendah sekitar 400 nmol/L sampai kadar $>1.500 \mathrm{nmol} / \mathrm{L}$, dalam waktu 4-6 jam setelah stres.

Sebenarnya terdapat beberapa hormon penanda respons stres, tetapi kortisol dapat menjadi penanda proses penyembuhan dengan kadar yang tinggi akan memperlama penyembuhan, menyebabkan komplikasi pada respirasi, serta mengganggu fungsi jantung dan imunosupresi. ${ }^{6}$ Meta-analisis terhadap 19 studi dengan 844 subjek dengan pemberian dexmedetomidine disbanding dengan kelompok kontrol didapatkan kadar kortisol pascapembedahan lebih rendah. Terdapat 16 studi membandingkan dexmedetomidine dengan normal salin, dan 3 studi membandingkan dengan obat anestesi (fentanyl, remifentanyl dan propofol). Jenis operasi dalam metaanalisis ini adalah operasi kraniotomi, bedah jantung dan vaskular, bedah ortopedi, bedah digestif seperti hepatektomi, esofagektomi, gastrektomi, dan operasi ginekologi. ${ }^{6 .}{ }^{9-13}$ Temuan dalam metaanalisis ini adalah pemberian dexmedetomidine dapat menurunkan kadar kortisol secara signifikan dibanding dengan kelompok $\mathrm{NaCl}$ ataupun kelompok obat anestesi. ${ }^{11}$

Dexmedetomidine merupakan agonis $\alpha-_{2}$ reseptor yang lebih spesifik dan poten dibanding dengan klonidin. $\alpha_{-}$reseptor banyak berada di lokus seruleus pons yang merupakan sumber persarafan simpatis dan mengatur kewaspadaan. Efek sedasi dari dexmedetomidine merupakan hasil dari penghambatan lokus seruleus tersebut., 9, 14-16

Dexmedetomidine memiliki komponen imidazol yang dapat menhambat enzim sitokrom P450. Enzim tersebutberfungsi dalam sintesis kortisol sehingga kemungkinan kadar kortisol menjadi turun karena mekanisme tersebut. Namun, mekanisme kerja pasti dari dexmedetomidine dalam memengaruhi kadar kortisol masih belum jelas. . $, 8,17,18$

Struktur imidazol dari dexmedetomidine juga menghambat cholesterol side-chain cleavage enzyme. Enzim ini berlokasi di mitokondria korteks adrenal yang juga berfungsi dalam produksi kortisol. 1,6,8,17-20 Keterbatasan dalam penelitian ini adalah nyeri pascaoperasi yang tidak dinilai, sedangkan dexmedetomidine juga memiliki efek analgesia selain sedasi dan pada penelitian ini hanya mengukur kadar kortisol sebagai penanda respons stres dari sekian banyak hormon penanda stres lainnya.

\section{Simpulan}

Kadar kortisol meningkat pada kedua kelompok dibanding nilai awal, namun kadar kortisol lebih rendah pada kelompok dexmedetomidine dibanding dengan kelompok plasebo. Tidak terjadi komplikasi pada pemberian dexmedetomidine. 


\section{Daftar Pustaka}

1. Desborough JP. The stress responsse to trauma and surgery. Br J Anaesth. 2000;85:109-17.

2. Guyton AC, Hall JE. Adrenocortical hormones. Dalam: Hall JE, penyunting. Guyton and Hall textbook of medical physiology. Edisi ke-13. Philadelphia: Elsevier Saunders; 2016. hlm. 965-81.

3. Moitra VK. Normal endocrine function. Dalam: Flood P, Rathmell JP, Shafer S, penyunting. Stoelting's pharmacology \& physiology in anesthetic practice. Edisi ke-5. Wolters Kluwer Health. Philadelphia: Lippincott Williams \& Wilkins; 2015. hlm. 1113-56.

4. Schwartz JJ, Akhtar S, Rosenbaum SH. Endocrine function. Dalam: Barash PG, Cullen BF, Stoelting RK, penyunting. Clinical anesthesia. Edisi ke-7. Philadelphia: Lippincot Williams and Wilkins; 2013. hlm. 1339-51.

5. Akhtar S, Barash PG, Inzucchi SE. Scientific principles and clinical implications of perioperative glucose regulation and control. Anesth Analg. 2010;110(2):481.

6. Wang XW, Cao JB, Lv BS, Mi WD, Wang ZQ, Zhang C, dkk. Effects of perioperative dexmedetomidine on the endocrine modulators of stress response: a metaanalysis. Clin Experiment Pharmacol Physiol. 2015;42:828-36.

7. Butterworth JF, Mackey DC, Wasnick JD. Adrenergic agonists \& antagonists. Dalam: Butterworth JF, Mackey DC, Wasnick JD, penyunting. Morgan \& Mikhail's clinical anesthesiology. New York: McGraw-Hill; 2013. hlm. 240.

8. Venn RM, Bryant A, Hall GM, Grounds RM. Effects of dexmedetomidine on adrenocortical function, and the cardiovascular, endocrine and inflammatory responsses in post-operative patients needing sedation in the intensive care unit. Br J Anaesth. 2001;86(5):650-6.

9. Yacout AG, Osman HA, Abdel-Daem MH, Hammouda SA, Elsawy MM. Effects of intravenous dexmedetomidine infusion on some proinflammatory cytokines, stress hormones and recovery profile in major abdominal surgery. Alexandria Med. 2011;4(1):3-8.

10. Bekker A, Haile M, Kline R, Didehvar S, Babu R, Martiniuk F, dkk. The effect of intraoperative infusion of dexmedetomidine on the quality of recovery after major spinal surgery. J Neurosurg Anesthesiol. 2013;25:16-24.

11. Wang ZX, Huang CY, Hua YP, Huang WQ Deng LH, Liu KX. Dexmedetomidine reduces intestinal and hepatic injury after hepatectomy with inflow occlusion under general anesthesia: A randomized controlled trial. $\mathrm{Br} \mathrm{J}$ Anaesth. 2014;112:1055-64.

12. Naguib AN, Tobias JD, Hall MW, Cismowski MJ, Miao Y, Barry ND, dkk. The role of different anesthetic techniques in altering the stress responsse during cardiac surgery in children: a prospective, double blinded, and randomized study. Pediatr Crit Care Med. 2013;14:481-90.

13. El Tahan MR, Mowafi HA, Al Sheikh IH, Khidr AM, Al Juhaiman RA. Efficacy of dexmedetomidine in supressing cardiovascular and hormonal responsses to general anesthesia for caesarean delivery: a dose-response study. Int J Obstet Anesth. 2012;21:222-9.

14. Nguyen V, Tieman D, Park E, Salehi A. Alpha-2 agonists. Anesthesiol Clin. 2017;35(2):233-45.

15. Rathmell JP, Rosow CE. Intravenous sedatives and hypnotics. Dalam: Flood P, Rathmell JP, Shafer S, penyunting. Stoelting's pharmacology and physiology in anesthetic practice. Edisi ke-5. Alphen aan den Rijn: Wolters Kluwer Health; 2015. hlm.142-3.

16. Warren S, Sebastian J. Dexmedetomidine: its use in intensive care medicine and anaesthesia. Br J Anaesth. 2015;16(7):2426.

17. Gertler R, Brown HC, Mitchell DH, Silvius EN. Dexmedetomidine: a novel sedativeanalgesic agent. Baylor University Medical Centre Proceedings. 2001;14(1):13-21. 
18. Barrett KE, Barman SM, Boitano S, Brooks HL. The adrenal medulla \& adrenal cortex. Dalam: Barrett KE, Barman SM, Boitano S, Brooks HL, penyunting. Ganong's review of medical physiology. Edisi ke-25. McGrawHill; 2016. hlm. 353-70.

19. Odeniyi IA, Fasanmade OA, Ogbera AO, Ohwovoriole AE. Body mass index and its effect on serum cortisol level. Nigerian J Clin Pract. 2015;18(2):194-7.

20. Turan G, Ozgultekin A, Turan C, Dincer E, Yuksel G. Advantageous effects of dexmedetomidine on haemodynamic and recovery responsses during extubation for intracranial surgery. Eur J Anaesthesiol. 2008;25:816-20. 